\section{ENGINEERING SOLUTIONS TO THE LONG-TERM STABILIZATION AND ISOLATION OF URANIUM MILL TAILINGS IN THE UNITED STATES}

\author{
Donald R. Sanders \\ Engineering and Design Manager \\ UMTRA Project \\ Morrison Knudsen Environmental Services \\ San Francisco, California \\ John C. Lommler \\ Lead Project Engineer \\ UMTRA Project \\ AGRA Earth and Environmental, Inc. \\ Albuquerque, New Mexico
}

\begin{abstract}
Engineering solutions to the safe and environmentally protective disposal and isolation of uranium mill tailings in the United States include many factors. Cover design, materials selection, civil engineering, erosive forces, and cost effectiveness are only a few of those factors described in this paper. The systems approach to the engineering solutions employed in the United States is described, with emphasis on the standards prescribed for the Uranium Mill Tailings Remedial Action Project. Stabilization and isolation of the tailings from humans and the environment are the primary goals of the U.S. uranium mill tailings control standards. The performance of cover designs with respect to water infiltration, radon exhalation, geotechnical stability, erosion protection, human and animal intrusion prevention, and longevity are addressed. The need for and frequency of surveillance efforts to ensure continued disposal system performance are also assessed.
\end{abstract}
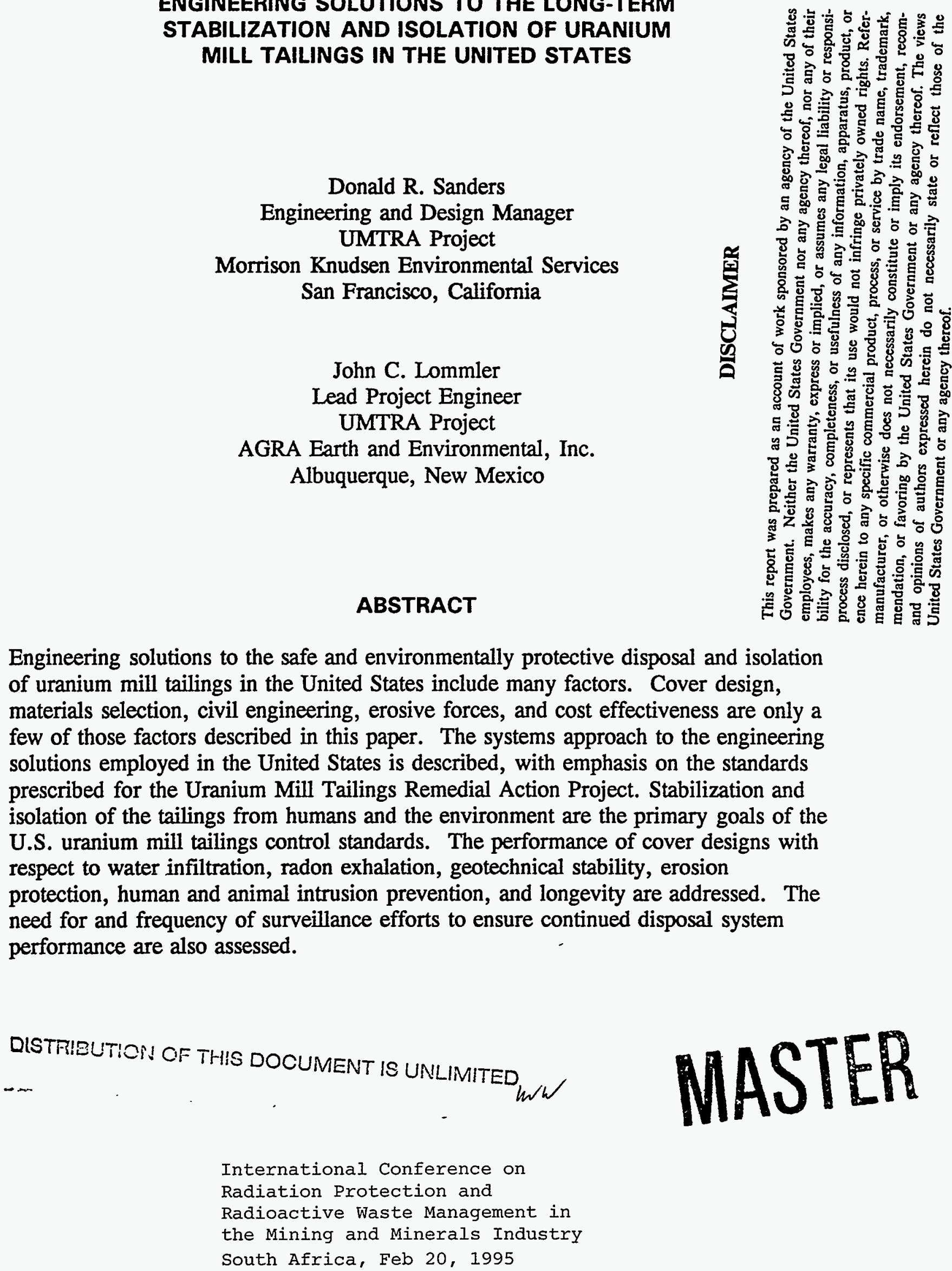

International Conference on

Radiation Protection and

the Mining and Minerals Industry

South Africa, Feb 20, 1995 


\section{DISCLAIMER}

Portions of this document may be illegible in electronic image products. Images are produced from the best available original document. 


\section{INTRODUCTION}

Engineering solutions for the long-term stabilization and isolation of uranium mill tailings in the United States have been developed and refined during the implementation of the U.S. Department of Energy's (DOE) Uranium Mill Tailings Remedial Action (UMTRA) Project. Over the past 11 years, the UMTRA Project has successfully cleaned up 14 abandoned uranium processing sites and has constructed 10 disposal embankments. The design for the remaining nine disposal sites has been completed, and remedial construction is under way at five of these sites.

The engineering solutions developed for the UMTRA Project have been dictated by conservative prescriptive design standards. These standards require the effective control of radon releases, protection of ground water, and isolation of the tailings from the environment for up to 1000 years to the extent reasonably achievable, and, in any case, for at least 200 years. Because of this design life requirement, the engineering solutions must rely primarily on the use of passive controls; active controls (such as the use of warning signs or an ongoing maintenance and repair program) can be used only as a supplementary system of control.

The current set of engineering and design procedures for the UMTRA Project is the result of many years of experience. Because the UMTRA Project consists of 19 separate disposal sites, project engineers have had to develop unique solutions for each site. However, the experience gained from each disposal site design was applied to subsequent site designs. The longevity of the project also has enabled the project design team to develop a level of trust and understanding with the technical review staff of the federal licensing authority (the U.S. Nuclear Regulatory Commission [NRC]), which has resulted in continuous improvement in the engineering solutions. Two examples of recent and ongoing developments in the design of uranium mill tailings disposal site covers are described later.

\section{PROJECT DESCRIPTION}

\section{Background}

The UMTRA Project was initiated when the U.S. Congress passed the Uranium Mill Tailings Radiation Control Act of 1978. This law required the remediation of 24 specific inactive uranium processing sites located in 10 states. It also directed the U.S. Environmental Protection Agency (EPA) to develop general design and performance standards for the remediation of the designated UMTRA Project sites, and designated the DOE as the agency responsible for remediation. The NRC was designated as the regulatory agency for the project. In this role, the NRC must review and approve remedial action plans and any subsequent significant design 
revisions. Because funding for the UMTRA Project is shared between the federal government ( 90 percent) and the state government where each site is located (10 percent), concurrence on the remedial designs also must be obtained from the appropriate state.

\section{Public Health and Environmental Risks}

The purpose of the Uranium Mill Tailings Radiation Control Act and the federal standards established for remedial action is to alleviate public health and environmental risks associated with uncontrolled uranium mill tailings. Uranium mill tailings can affect humans through the following four principal pathways:

- Diffusion of radon-222, a decay product of radium-226, from tailings into indoor air.

- Direct exposure to gamma radiation.

- Dispersal of radioactive airborne particulates.

- Waterborne transport of radioactive and toxic constituents.

Long-term exposure to radon is considered the dominant radiation hazard from tailings. The greatest risks are to persons who have tailings in or around their houses where concentrations of short-lived decay products of radon can build up in the indoor air. Breathing radon-222 (an inert gas) and its short half-life decay products, which attach to tiny dust particles, exposes the lungs to alpha radiation which can increase the potential for developing lung cancer. During remedial action, the greatest health risk to on-site workers is from radioactive dust particles. Wind and water dispersal of unstabilized tailings or leaching of precipitation through tailings can carry radioactive and other toxic materials to surface or ground water. The levels of contamination from these pathways are generally very low. However, some longterm future contamination of surface and ground water and subsequent intake by humans and other life are possible.

\section{Health and Environmental Standards}

Like all environmental remediation projects, the engineering solutions for the UMTRA Project must satisfy certain legal standards. For the remediation of uranium mill tailings in the United States, these standards have been promulgated by the EPA. 
The objectives of the standards for remedial actions at inactive uranium processing sites in the United States are as follows (EPA 1983, EPA 1995):

- Isolate and stabilize UMTRA Project tailings and other radiologically contaminated materials, collectively referred to by law as residual radioactive materials (RRM).

- Prevent future human contact with tailings.

- Prevent the dispersal of tailings in the environment by natural forces.

- Reduce radon emissions from tailings to reduce health risks to people living or working near the tailings piles.

- Reduce the health risk to the population as a whole by protecting surface and ground water.

The UMTRA Project standards govern two types of remedial activities: cleanup and control. Cleanup is the operation that reduces the potential health consequences of tailings that have been dispersed from tailings piles. Control is the operation that places the tailings in a location that will minimize the risk to humans for the long term.

The design standards for the control (i.e., disposal) of uranium mill tailings in the United States are deceptively simple:

"Control shall be designed to:

(a) Be effective for up to one thousand years, to the extent reasonably achievable, and, in any case, for at least 200 years, and,

(b) Provide reasonable assurance that releases of radon-222 from residual radioactive material to the atmosphere will not:

(1) Exceed an average release rate of 20 picocuries per square meter per second or

(2) Increase the annual average concentration of radon-222 in air at or above any location outside the disposal site by more than one-half picocurie per liter."

The design standards also provide for the protection of ground water by establishing maximum contaminant levels for a specific list of constituents. 
As will be discussed later, it is the 1000-/200-year design life standard that has created the greatest challenge to developing engineering solutions for the UMTRA Project.

\section{Site Conditions and Status}

Figure 1 shows the locations of the UMTRA Project sites. Table 1 lists statistics for each site, including the volume of tailings cleaned up, radioactivity levels, and type of disposal. The UMTRA Project sites are located primarily in the Rocky Mountain and Colorado Plateau regions of the western United States. Most of these sites are located at relatively high elevations, in semiarid environments with relatively severe winters. There are some exceptions, however. The Canonsburg, Pennsylvania, site is located in a humid-continental climate, and the Falls City, Texas, site is located in a subtropical climate.

Climatological and meteorological conditions that must be considered in the design of each disposal site include rainfall (total amount, yearly distribution, and intensity), evaporation rates, number of days per year with below-freezing temperatures, and maximum frost depth.

Topography, geology, and geomorphic processes also play important roles in the design of tailings disposal sites. For example, site topography determines the layout and geometry of the disposal embankment. The geologic setting is important in terms of foundation permeability, ease of excavation, location of suitable size and quality of rock cover materials, location of suitable materials for constructing low-permeability covers, and seismic forces. Site-specific geomorphic processes that must be considered in the design of disposal embankments include landsliding, erosion caused by stream meanders, and headcutting by intermittent washes.

\section{DISPOSAL SITE SELECTION}

In selecting a disposal site for stabilization of tailings materials, project engineers must evaluate public health and safety impacts; current land use; natural erosion processes; potential intrusion by humans, vegetation, animals, or insects; economic considerations; and local construction practices. UMTRA Project RRM are generally stabilized by one of three procedures: stabilization in place by consolidating material in a compact shaped disposal embankment; stabilization on-site by relocating contaminated materials to a more suitable location within the processing site boundaries; or relocation of the material to an off-site location. All three options may involve disposal facility designs that vary from an entirely above-grade disposal facility to an entirely below-grade or partially below-grade facility. 


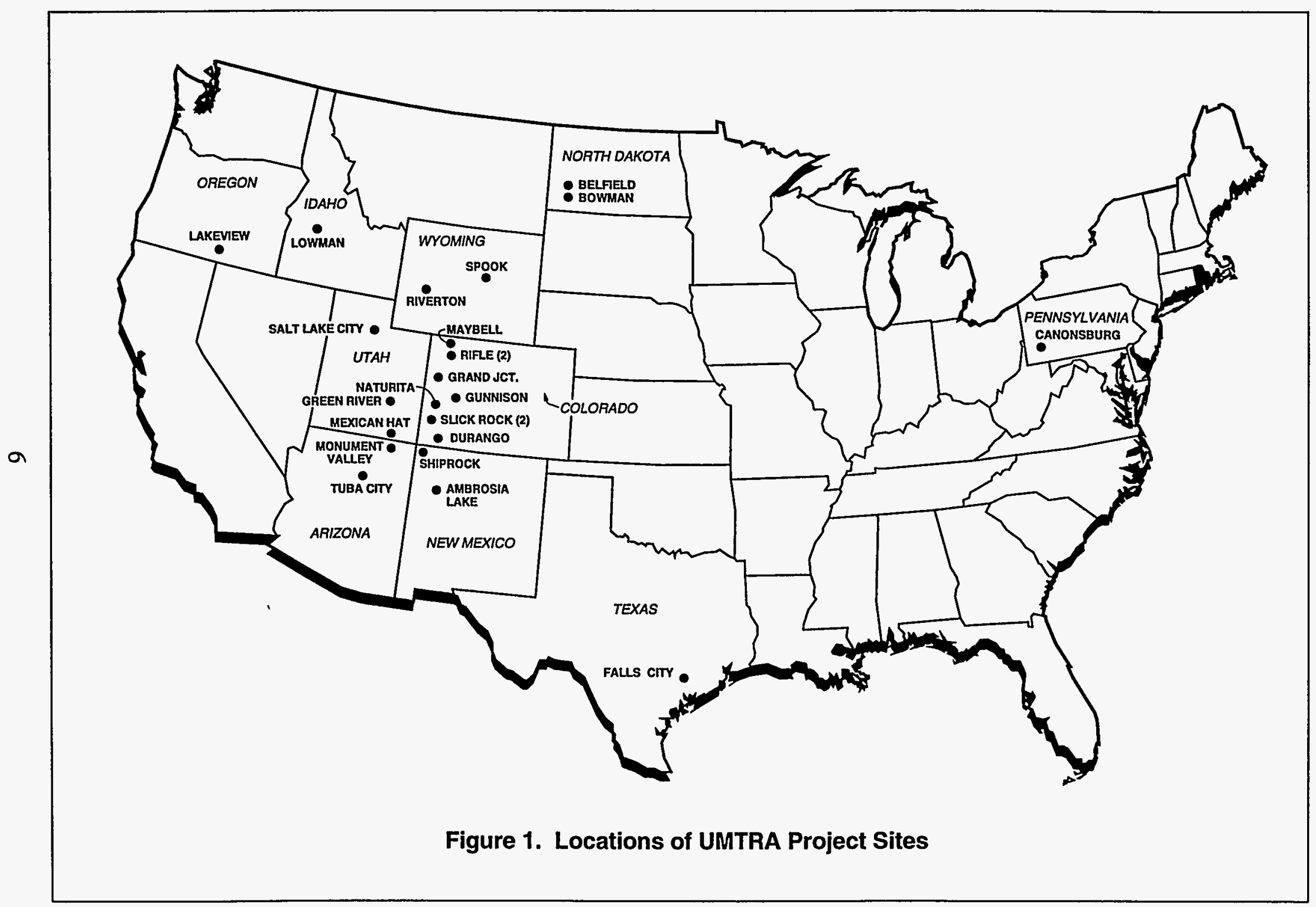


Table 1. Summary Statistics for UMTRA Project Disposal Sites

\begin{tabular}{|c|c|c|c|c|c|c|c|}
\hline Site & $\begin{array}{l}\text { Disposal } \\
\text { Option }^{\mathrm{a}}\end{array}$ & $\begin{array}{c}\text { Volume of } \\
\text { RRM } \\
\text { Stabilized } \\
\left(\mathbf{M m}^{3}\right)\end{array}$ & $\begin{array}{c}\text { Volume of } \\
\text { RRM Moved } \\
\left(\mathbf{M m}^{3}\right)\end{array}$ & $\begin{array}{c}\text { Haul } \\
\text { Distance } \\
\text { (km) }\end{array}$ & $\begin{array}{l}\text { Topslope } \\
\text { Cover } \\
\text { Type }\end{array}$ & $\begin{array}{l}\text { Construction } \\
\text { Dates }\end{array}$ & $\begin{array}{c}\text { Average } \\
\text { Radioactivity } \\
\text { (pCi/g) }\end{array}$ \\
\hline Ambrosia Lake, New Mexico & SIP & 4.15 & 2.57 & 0.1 & Rock & $09 / 92-04 / 95$ & 281 \\
\hline Belfield/Bowman, North Dakota & REL/SIP & 0.09 & 0.04 & 113 & Rock & $04 / 96-12 / 96$ & 55 \\
\hline Canonsburg, Pennsylvania & SIP & 0.16 & 0.16 & 0.1 & Vegetation & $10 / 83-12 / 85$ & 500 \\
\hline Durango, Colorado & REL & 1.64 & 1.64 & 5.6 & Vegetation & $12 / 86-05 / 91$ & 436 \\
\hline Falls City, Texas & SIP/SOS & 4.45 & 2.70 & 1.6 & Vegetation & $01 / 92-08 / 94$ & 197 \\
\hline Grand Junction, Colorado & REL & 4.03 & 4.03 & 30 & Rock & 04/88 - Present & 340 \\
\hline Green River, Utah & sos & 0.26 & 0.26 & 0.2 & Rock & $09 / 88-12 / 89$ & 66 \\
\hline Gunnison, Colorado & REL & 0.57 & 0.57 & 11.3 & Rock & 06/92 - Present & 214 \\
\hline Lakeview, Oregon & REL & 0.72 & 0.72 & 12 & Vegetation & $06 / 86-10 / 87$ & 70 \\
\hline Lowman, Idaho & SIP & 0.10 & 0.10 & 0.1 & Rock & $04 / 91-10 / 91$ & 59 \\
\hline Maybell, Colorado & SIP & 2.34 & 0.39 & 0.1 & Rock & $04 / 95-12 / 96$ & 155 \\
\hline Mexican Hat, Utah & SIP/SOS & 2.12 & 0.87 & 0.1 & Rock & $06 / 92-02 / 95$ & 670 \\
\hline Monument Valley, Arizona & REL & 0.78 & 0.78 & 28 & Rock & $06 / 92-11 / 94$ & 50 \\
\hline Naturita, Colorado & REL & 0.39 & 0.39 & 9.6 & Rock & $05 / 95-09 / 96$ & 116 \\
\hline Rifle, Colorado & REL & 2.66 & 2.66 & 12 & Rock & $04 / 92-05 / 96$ & 600 \\
\hline Riverton, Wyoming & REL & 1.37 & 1.37 & 76 & b & $04 / 88-11 / 89$ & 292 \\
\hline
\end{tabular}


Table 1. Summary Statistics for UMTRA Project Disposal Sites (Concluded)

\begin{tabular}{|c|c|c|c|c|c|c|c|}
\hline Site & $\begin{array}{l}\text { Disposal } \\
\text { Option }^{\mathrm{a}} \\
\end{array}$ & $\begin{array}{c}\text { Volume of } \\
\text { RRM } \\
\text { Stabilized } \\
\left(\mathbf{M m}^{3}\right) \\
\end{array}$ & $\begin{array}{c}\begin{array}{c}\text { Volume of } \\
\text { RRM Moved } \\
\left(\mathrm{Mm}^{3}\right)\end{array} \\
\end{array}$ & $\begin{array}{c}\text { Haul } \\
\text { Distance } \\
(\mathbf{k m}) \\
\end{array}$ & $\begin{array}{c}\text { Topslope } \\
\text { Cover } \\
\text { Type } \\
\end{array}$ & $\begin{array}{c}\text { Construction } \\
\text { Dates } \\
\end{array}$ & $\begin{array}{c}\text { Average } \\
\text { Radioactivity } \\
\text { (pCi/g) }\end{array}$ \\
\hline Salt Lake City, Utah & REL & 2.14 & 2.14 & 116 & Rock & $01 / 85-09 / 88$ & 395 \\
\hline Shiprock, New Mexico & SIP & 0.96 & 0.79 & 0.1 & Rock & $06 / 85-09 / 86$ & 404 \\
\hline Slick Rock, Colorado & REL & 0.48 & 0.48 & 10 & Rock & $05 / 95-10 / 96$ & 140 \\
\hline Spook, Wyoming & SIP & 0.25 & 0.03 & 0.1 & Soil & $04 / 89-11 / 89$ & 310 \\
\hline Tuba City, Arizona & SIP & 1.56 & 0.75 & 0.1 & Rock & $07 / 88-03 / 89$ & 470 \\
\hline Total Volumes & & 31.8 & 23.25 & & & & \\
\hline \multicolumn{8}{|l|}{$\begin{array}{l}\text { a SIP = stabilized in place; SO } \\
{ }^{\mathrm{b}} \text { Tailings were combined with } \\
\mathrm{Mm}^{3} \text { - million cubic meters } \\
\mathrm{km} \text { - kilometer } \\
\text { pCi/g - picocuries per gram }\end{array}$} \\
\hline
\end{tabular}


To evaluate alternative disposal cell locations and designs, the following steps are taken (DOE 1989):

1. Identify health and environmental hazards associated with stabilizing RRM in place; determine whether (and how) remedial actions can meet technical criteria and prescriptive standards.

2. Assess hazards and design requirements necessary to stabilize RRM on the site.

3. Identify potential alternative sites for relocation of RRM.

4. Identify hazards and potential design alternatives for each of the disposal options and sites.

5. Perform cost estimates and construction feasibility analyses for each of the three disposal options.

6. Select the preferred option for stabilization of RRM and a final configuration of the disposal cell based on cost and the amount of risk associated with factors that cannot be fully quantified.

The following major design objectives are considered in the site selection process: minimizing the distance of the disposal site from the processing site; avoiding natural hazards such as earthquake-prone geologic structures, unstable slopes, soft/compressible foundation soils, major river floodplains, and shallow ground water; and avoiding areas of human habitation.

Frequently, it is not possible to avoid all hazards. Therefore, UMTRA Project disposal cell designs require application of civil engineering, earthquake engineering, and geotechnical engineering principles to design for earthquakes, rainfall/runoff/river erosion, marginal foundation conditions, contaminant transport in ground water, and treatment of ground water. Publications describing standard UMTRA Project cell design procedures include the Technical Approach Document (DOE 1989) and the Morrison Knudsen Design Procedures Manual (Morrison Knudsen Corporation 1989).

\section{DISPOSAL CELL DESIGN}

The cover for an UMTRA Project tailings disposal cell must satisfy three basic design objectives: controlling the release of radon- 222 from the tailings into the atmosphere; limiting the infiltration of rainwater and snowmelt into the tailings; and preventing the dispersal of tailings into the environment for at least 200 years, and up to 1000 years to the extent possible. 
A typical UMTRA Project disposal cell cover consists of four layers overlying the tailings, but some covers have used up to nine layers. The basic four-layer cover system is shown in Figure 2. The four layers, from the surface downward, are as follows: an erosion protection layer (either rocks or a soil/vegetative layer); a bedding layer; an intermediate layer (often referred to as a frost protection layer); and a radon/infiltration barrier.

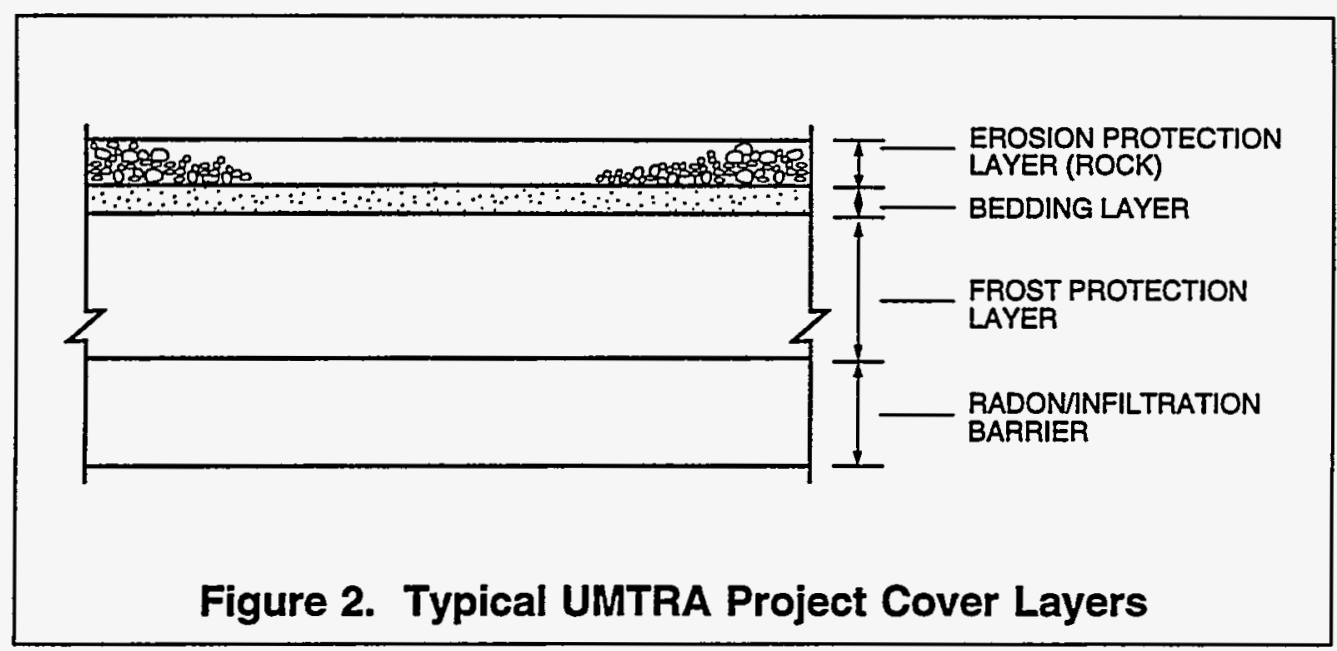

Many variables influence the design of the disposal cell and its cover systems, including tailings moisture content, tailings radioactivity, tailings shear strength, tailings compressibility, cover soil permeability and radon diffusion coefficients, design rainfall, maximum depth of freezing, and design earthquake acceleration. The design variables are not independent; therefore, the disposal cell and cover design must take into account all of the variables and their dependency on one another. This design approach is referred to as the "systems approach." The systems approach is often applied at UMTRA Project sites to try to combine component functions and achieve the most cost-effective solution. For example, soil in the freezing zone will be modified so that its permeability will often increase with time. The systems approach has worked well in the U.S. aerospace industry.

However, problems have been encountered when applying this approach to the UMTRA Project disposal cell design. One of the main problems is the set of prescriptive standards that is written into the law or is administratively applied by regulators that oversee the UMTRA Project. For example; the limiting radon flux to the atmosphere (20 picocuries per square meter per second), maximum cover permeability ( $1 \times 10^{-9}$ meter per second), and maximum ground water concentration limit for uranium (0.044 milligrams per liter) will likely not allow for design flexibility. The most critical design condition will control the radon/infiltration barrier design. Some design criteria may actually conflict. For example, if the area of a disposal embankment is minimized to reduce cost, the increased height of the pile 
can increase the rate and concentration of transient drainage and cause the ground water contamination maximum concentration limits to be exceeded.

Through experience, the UMTRA Project designers have determined which variables most frequently control the disposal cell design. The project engineers and scientists initially believed that control of radon emanations would control the cover layer design. Application of the systems approach led to designs which usually require placement of less-contaminated materials over more highly contaminated materials. The result: if the permeability of the radon barrier was controlled to less than $1 \times 10^{-9}$ meter per second, the radon diffusion coefficient of this barrier would be low enough to control the surface radon flux to less than 20 picocuries per square meter per second in nearly all cases. To reflect the increased importance of the radon barrier to also limit water infiltration, this low-permeability layer is now called the radon/infiltration barrier.

The low-permeability radon/infiltration barrier is constructed from well-compacted, fine-grained soils. This layer is protected by overlying layers of soil and/or rock. It has been found that the use of an intermediate layer over the radon/infiltration barrier provides several benefits, including an additional radon diffusion layer; increased confining stress on the radon/infiltration barrier, which decreases its permeability and radon diffusion coefficient; freeze-thaw protection for the radon/infiltration barrier; retardation of drying and cracking of the radon/infiltration barrier; lower installation costs per unit (the intermediate layer requirements are less stringent than the radon/infiltration barrier requirements); and biointrusion protection from roots and burrowing animals. Following is a description of the basic UMTRA Project cover design process.

\section{Radon Attenuation}

The radon attenuation design criterion for the radon/infiltration barrier is to limit the release of radon-222 to the atmosphere to not more than 20 picocuries per square meter per second above background levels averaged over the surface of the tailings disposal cell. Conformance with this standard is demonstrated by the use of the Radon Attenuation Effectiveness and Cover Optimization with Moisture (RAECOM) effects computer code (Rogers et al. 1984). The RAECOM code uses onedimensional diffusion modeling to predict the radon release rate from soils and tailings contaminated with radium-226. Input parameters for the RAECOM program include the following:

- Bulk densities and porosities of the tailings and radon barrier materials.

- Radon emanation fraction of the tailings. 
- Radon diffusion coefficients for the tailings and radon barrier materials.

- 15-bar capillary moisture contents of the tailings and radon barrier materials (simulates the conservative long-term moisture contents).

- Radium-226 concentrations of the tailings (including any calculated ingrowth of radium-226 from thorium-230).

- Ambient radon concentrations at the disposal site.

\section{Infiltration Control}

The design criterion for limiting the amount of water (rainfall and snowmelt) that passes through the radon/infiltration barrier is determined by the ground water protection strategy for the site and the permeability of the foundation materials underlying the disposal cell. The infiltration control criterion is generally expressed as the maximum saturated hydraulic conductivity value $(\mathrm{k})$ for the radon/infiltration barrier. The default maximum hydraulic conductivity for UMTRA Project radon/infiltration barriers is $1 \times 10^{-9}$ meter per second. The allowable hydraulic conductivity must be decreased if ground water modeling indicates that leachate flow from the tailings disposal cell will cause the UMTRA Project ground water standards to be exceeded in a potentially usable aquifer beyond the boundaries of the disposal site within 1000 years. A usable aquifer is defined as a water-bearing formation that can yield at least 150 gallons (568 liters) per day, contains less than 10,000 milligrams per liter of total dissolved solids, and does not currently contain widespread contamination. Also, the $\mathrm{k}$ value of the radon/infiltration layer will need to be less than $1 \times 10^{-9}$ meter per second if the underlying foundation materials of the disposal cell have a $\mathrm{k}$ value that is generally less than $5 \times 10^{-9}$ meters per second. If the $\mathrm{k}$ value of the radon/infiltration barrier is not sufficiently less than the $\mathrm{k}$ value of the cell's foundation, a phenomenon called the "bathtub" effect may occur. With this effect, a saturated zone forms at the base of the tailings. Buildup of saturation within the tailings may cause contaminated water to leak to the surface through the sides of the disposal cell or cause contamination to seep into ground water at a faster rate. Methods for predicting the potential for the bathtub effect are described in greater detail in the next section of this paper.

\section{Frost Protection}

The radon/infiltration barrier must be protected against the adverse effect that freezing and thawing can have on its permeability. Freezing and thawing of most lowpermeability clayey soils used for radon/infiltration barriers will increase the saturated hydraulic conductivity of the soil by an order of magnitude or greater (Kim and Daniel 1992, Othman et al. 1994). Therefore, a rather simple method of protecting 
the radon/infiltration layer is to place enough soil above it so that it lies below the predicted frost depth. At some UMTRA Project disposal sites, up to 2.1 meters of frost protection material have been required.

Because the frost protection layer can add significantly to the construction cost, an alternative radon/infiltration barrier design is being analyzed. This design would eliminate the need for the frost protection layer. It relies on the unique properties of sand-bentonite mixtures, whose hydraulic conductivity characteristic does not appear to change when the mixtures are subjected to repeated freezing and thawing. Laboratory testing and analyses are under way to demonstrate that such sand-bentonite mixtures do not need frost protection layers.

\section{Biointrusion Protection}

The radon/infiltration barrier also must be protected from the potential adverse effects of plant roots and burrowing animals. Disposal cells designed with rock sideslopes and topslopes for erosion protection generally protect the radon/infiltration barrier from these biological phenomena. For disposal cells designed with vegetative covers, additional engineering solutions are required (such as adding a biointrusion protection layer of rock below the surface or adding choked rock to the surface soil layer). Regardless of the engineering solution used, a long-term surveillance program is recommended to provide assurance that deep-rooted plants and burrowing animals do not adversely affect the overall average permeability and radon attenuation function of the radon/infiltration barrier.

\section{Erosion Protection}

The primary purpose of the erosion protection layer is to protect the underlying layers-the frost protection layer, radon/infiltration barrier, and tailings-from water and wind erosion. The secondary purpose of the erosion protection layer is to retard desiccation and potential invasion of underlying layers by plant roots and burrowing animals.

The dominant design criterion for the erosion protection layer is the design rainfall event. Because of the need to satisfy the design life standard, the project regulators have determined that the design rainfall event should be the probable maximum precipitation (PMP) for the disposal site. Once the PMP is calculated, the required thickness of the erosion protection layer and the size distribution of the rock (riprap) layer are calculated using the computer program RPRP/SFST (Morrison Knudsen Engineers 1987). Riprap layer thicknesses are minimized to fit the largest particles, except where thicker layers are needed in zones of high turbulence. Riprap layer thicknesses are a minimum of a 0.15 meter on gently graded topslopes with highquality rock and 0.30 meter elsewhere. Because of the requirement to use the PMP 
as the design storm, all UMTRA Project disposal cell sideslopes are protected with riprap.

\section{Cover Analyses}

After the specifications for the various cover layers have been determined (thickness, permeability, rock size distribution, etc.), the cover system is subjected to various stability analyses. These include slope stability analyses under static and seismic loadings. The design earthquake used for the seismic stability analysis is the maximum credible earthquake. As a result, the maximum slopes used on the sides of UMTRA Project disposal embankments to date have been 20 percent $(5$ horizontal to 1 vertical), with only one exception. The maximum differential settlement and horizontal strains in the cover are determined to ensure that the radon/infiltration barrier will not crack.

Finally, before the disposal cell design is completed, it is subjected to cost, schedule, and constructability reviews. These reviews have proven very beneficial for the UMTRA Project, particularly the review findings from the project construction management group. Lessons learned from previously completed disposal sites provide useful feedback to the designers, which results in more practical, more adaptable, and less costly engineering solutions to the long-term stabilization and isolation of the tailings.

\section{RECENT DEVELOPMENTS IN DISPOSAL CELL AND COVER DESIGNS}

Since the release of the UMTRA Project's Technical Approach Document in 1989, several new developments have been applied to the UMTRA Project disposal cell design process. Two of these recent developments address the following issues: using laboratory versus field permeability test results, and avoiding the bathtub effect.

\section{Laboratory Versus Field Permeability Test Results}

In the United States in the early 1980s, it was standard landfill and UMTRA Project design practice to obtain several representative soil samples of candidate infiltration layer soils from test pits and test them at or wet of optimum moisture content in the laboratory in a constant-head or falling-head permeameter to determine the design permeability of the potential radon/infiltration barrier layer soils.

With time, it became apparent from UMTRA Project experience and from published geotechnical data that the laboratory permeability (hydraulic conductivity) of a compacted clay layer was not necessarily a reliable indicator of the effective field permeability. Evidence was available, even prior to 1980, that soils tested in small 
laboratory samples had a lower permeability than identical soils tested in larger laboratory samples (Rowe 1972). The reason for these differing permeability values was soil structure; that is, the small-scale versus large-scale structure in clay soil samples. Tests on small soil samples were measuring the small-scale, or microstructure, permeability (that is, the permeability controlled by soil pore size). Tests on larger samples were measuring the permeability value that is controlled by the soil's macrostructure. Macrostructure permeability in compacted clayey soils is primarily the result of cracks or voids between clods of soil that were pressed together by the compaction process (Daniel 1984).

To simulate field permeability values for use in designing disposal cell covers, it is necessary to simulate clay field conditions in the test used or to reduce differences between laboratory and field conditions as much as possible. Some engineers insist that the microstructure versus macrostructure findings discussed above necessitate that only field permeability tests be used. Field permeability testing has advantages and disadvantages (Daniel 1989, Havlena and Stephens 1991). The advantages are as follows:

- The compaction equipment used to construct the radon/infiltration barrier can be used to construct the field test pad.

- The test area included in field permeability tests such as the sealed double ring infiltrometer (SDRI) test can be made large enough to be representative of the large-scale structure constructed in the field.

- A vertical flow field through saturated to unsaturated soil, which simulates actual field conditions, can be generated.

- Field test equipment such as that used in the SDRI procedure are designed to accurately measure very small water flows, which makes them suitable for testing low-permeability materials.

The disadvantages of field permeability testing are as follows:

- Compared to laboratory testing, field permeability tests such as the SDRI test are expensive and time-consuming (usually taking several weeks to months to complete).

- Since the field test apparatus is large and the test procedure costly, few tests are conducted, leaving questions about the statistical significance of the results.

- Field tests such as the SDRI test measure infiltration and not permeability, because the wetting-front suction head (needed to calculate the gradient) is generally not 
known and must be estimated. If the wetting-front suction head is measured by additional testing, the actual permeability can be calculated.

- Since the field permeability tests (except the borehole test) are performed on or near the surface of a test fill, the actual confining stress experienced by the radon/ infiltration barrier (which is normally buried approximately 1 to 3 meters below the ground surface) cannot be simulated.

One advantage of laboratory permeability testing is that a range of compaction moisture contents and densities can be tested to determine the range of potential permeability values that will likely be generated in cover layer construction. To make the laboratory permeability testing results representative of field conditions, representative samples of soil need to be compacted by a method that simulates field conditions or a field test pad needs to be constructed and sampled. Samples can be obtained from a test pad by using thin-walled sample tubes or by cutting blocks by hand. To get as much of the clod structure as possible, laboratory sample diameters should be at least 8 to 10 centimeters. To simulate appropriate confining stresses in the permeability test, a triaxial permeameter should be used to confine the sample, provide pore water backpressure to ensure sample saturation, and provide assurance that flow into the sample equals flow out of the sample. In some cases, the permeating fluid affects the measured permeability of the sample. In such cases, laboratory batch tests can be performed to simulate the effect of the real leachate on permeability test results relative to those results of tests performed using water.

Finally, selection of field permeability or laboratory testing results for design practice should be carefully examined. Factors such as the maximum design hydraulic conductivity, the nature of the borrow source, and compliance with regulatory agency requirements need to be considered in the decision.

\section{The Bathtub Effect}

Predictions of the volume and quality of water drained from disposal cells is of considerable importance in convincing regulators that a cell design is suitable for licensing. In the process of stabilizing a tailings pile in place, the area of the pile typically is reduced by bringing in tailings from the perimeter of the pile and filling in the pond in the center of the pile. This process of reducing the pile's area and increasing its height increases the loading on soft, saturated slimes located inside the pile. As the vertical loading on the slimes increases, contaminated pore fluid is squeezed out of the pile into the subsurface, and subsequently into the ground water. Modeling and monitoring of this leachate flow into the ground water are required to determine whether EPA ground water contamination limits are being (or will be) exceeded. This contaminant flow is referred to as transient drainage, because it will eventually subside and steady-state flow conditions will develop. 
When tailings piles are relocated, slimes are compacted in place in disposal cells that are constructed on uncontaminated natural ground. These sites are often selected at remote locations where the ground water table is several tens or hundreds of meters below the ground surface. It would seem that leachate flow would not be a problem at such remote sites, but this is not always the case due to uncertainty in potential future ground water use.

Frequently, at a relocated site, a question arises about potential for buildup of leachate in the cell resulting in seepage of leachate from the perimeter of the cell. This phenomenon is referred to in the United States as the "bathtub" effect. To model partially saturated and saturated migration of moisture within and from the disposal cell, both from transient drainage and drainage from infiltration through the disposal cell cover, requires use of a saturated/unsaturated flow model. On the UMTRA Project, the UNSAT2 model has been used (Davis and Newman 1983).

As an example, the UNSAT2 model was used during the design of the UMTRA Project's Rifle, Colorado, site to determine the potential for creating a bathtub effect within the disposal cell. Based on the results of the study, the initial remedial design was modified to include a geomembrane system to contain the zone saturated with seepage; an operational foundation drain system to enhance the drainage of tailings fluids during the construction phase; and monitor wells that can be used to dewater the tailings during the construction of the disposal cell. Figure 3 predicts the extent of the saturated zone within the Rifle disposal cell 200 years following construction. As shown, the predicted elevation of the saturated zone within the tailings disposal cell will not exceed the elevation of the toe of the disposal cell.

\section{CONCLUSIONS AND LESSONS LEARNED}

With more than 12 years of experience in designing and constructing uranium mill tailings disposal facilities, the UMTRA Project design team can make the following conclusions regarding engineering solution for the long-term stabilization and isolation of uranium mill tailings in the United States:

- It is possible to design 1000 -year design-life disposal facilities that rely primarily on passive (i.e., engineered) controls; however, active controls such as long-term surveillance of these facilities are considered to be prudent backup for the continued performance of these facilities as designed.

- Although certain general design principles and procedures are common to each UMTRA Project disposal site design, each site is unique in terms of its geographic and geologic setting. This has required unique engineering solutions to satisfy the design standards established for the Project. 


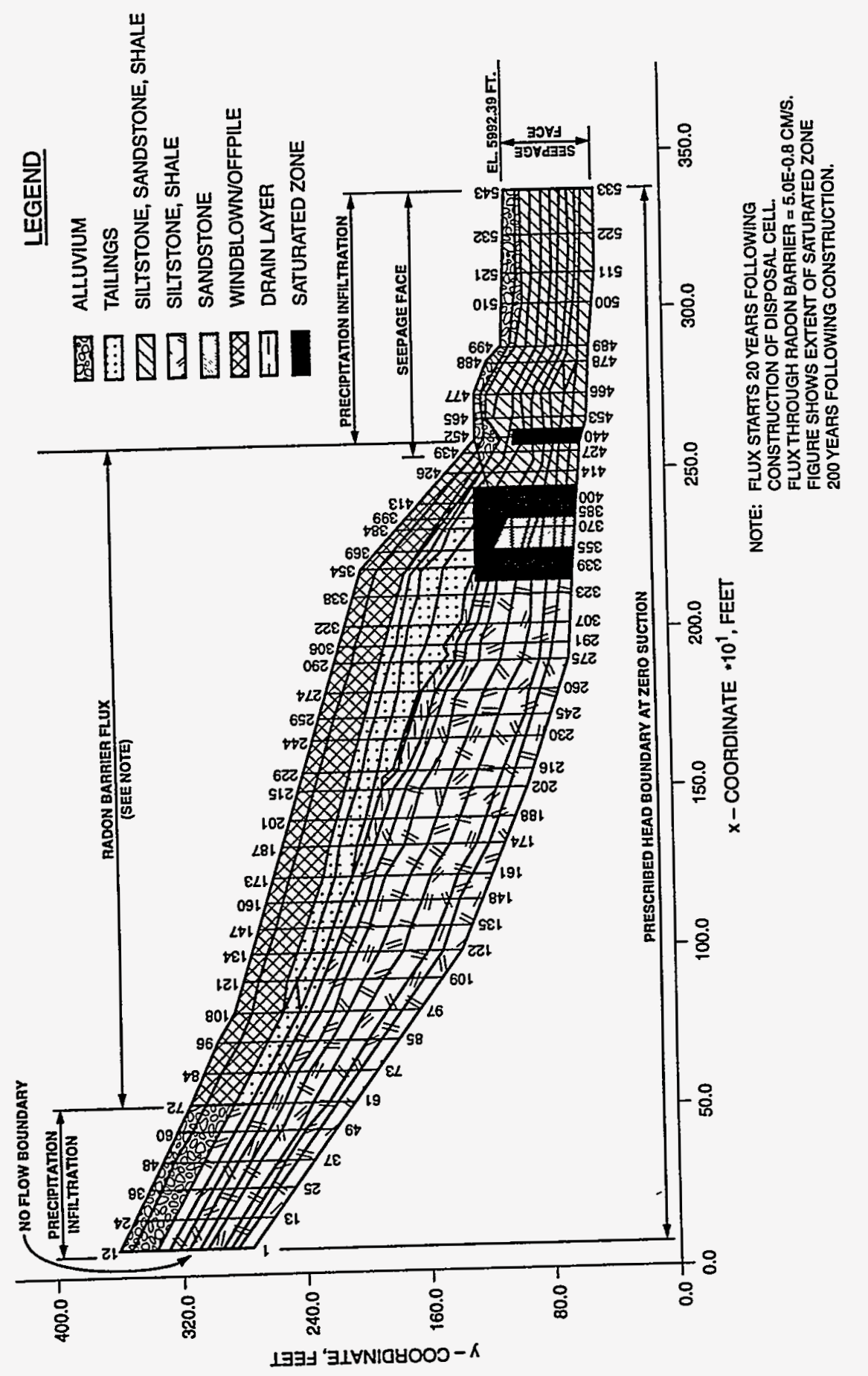

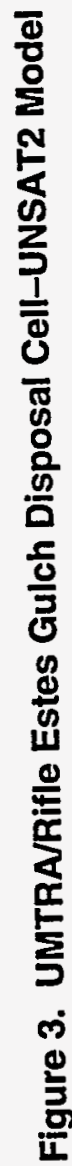


- The prescriptive design standard established for the long-term control of uranium mill tailings in the United States can result in overly conservative designs, but these standards have certain advantages over performance-based or risk-based standards. In general, the use of prescriptive standards simplifies the design review and approval process. Requirements for demonstrating compliance with the design standards are well understood by both the designers and regulators. The potential for disagreement between the designers on the one hand and the regulators and general public on the other is minimized. Further, the design process is shortened by avoiding the additional time and expense developing sitespecific risk assessments and obtaining agreement on the site-specific work with the regulators and the general public.

- Close coordination and communication between the design group and the construction management group has resulted in continuous improvement in the constructability of the engineering solution for tailings disposal facilities.

- The UMTRA Project is considered one of the most, if not the most, successful federal environmental remediation projects in the United States, despite the expanded scope and extended schedule for the UMTRA Project in comparison with the original estimates.

\section{REFERENCES}

Daniel, D. E. 1984. "Predicting Hydraulic Conductivity of Clay Liners," American Society of Civil Engineers, Journal of Geotechnical Engineering, Vol. 110, No. 2, February 1984, pp. 285-300.

Daniel, D. E. 1989. "In Situ Hydraulic Conductivity Tests for Compacted Clay," American Society of Civil Engineers, Journal of Geotechnical Engineering, Vol. 115, No. 9, September 1989, pp. 1205-1226.

Davis, L. A. and S. P. Newman 1983. "Documentation and Users' Guide," UNSAT2-Variably Saturated Flow Model (final report), prepared for the U.S. Nuclear Regulatory Commission, December 1983.

DOE 1989. Technical Approach Document, United States Department of Energy, UMTRA Project, Albuquerque, New Mexico, 290 pages.

EPA 1983. "Standards for Remedial Actions of Inactive Uranium Processing Sites," United States Environmental Protection Agency, Federal Register, Vol. 48, No. 3, January 5, 1983, pp. 590-606. 
EPA 1995. "Groundwater Standards for Remedial Actions at Inactive Uranium Processing Sites," United States Environmental Protection Agency, Federal Register, Vol. 60, No. 7, January 11, 1995, pp. 2854-2871.

Havlena, J. A., and D. B. Stephens 1991. "Vadose Zone Characterization Using Field Permeameters and Instrumentation," Current Practice in Ground Water and Vadose Zone Investigations, ASTM STP 1118, D.N. Nielsen and S. Martin, editors, American Society for Testing Materials, Philadelphia, Pennsylvania.

Kim, W. H., and D. E. Daniel 1992. "Effects of Freezing on Hydraulic Conductivity of Compacted Clay," American Society of Civil Engineers, Journal of Geotechnical Engineering, Vol. 118, No. 7, pp. 1083-1097.

Morrison Knudsen Engineers 1987. UMTRA Project-GEN "RPRP/SFST"-A Computer Program for Designing Riprap Protection for Sheet Flow Using Factor of Safety Method and/or Stephenson's Method, September 1987, unpublished.

Morrison Knudsen Corporation 1989. "UMTRA Design Procedures," seventh revision, January 1989, San Francisco, California.

Othman et al. (M. Othman, C. Benson, E. Chamberlain, and T. Zimmie) 1994. "Laboratory Testing to Evaluate Changes in Hydraulic Conductivity of Compacted Clays Caused by Freeze-Thaw: State-of-the-Art," ASTM STP 1142, Hydraulic Conductivity and Waste Contaminant Transport in Soils, D.E. Daniel, S.J. Trautwein, editors, Philadelphia, Pennsylvania.

Rogers et al. (V. C. Rogers, K. K. Nielson, and D. R. Kalkward) 1984. "Radon Attenuation Handbook for Uranium Mill Tailings Cover Design," NUREG CR/3533, prepared for the U.S. Nuclear Regulatory Commission, April 1984.

Rowe, P. W. 1972. "The Relevance of Soil Fabric to Site Investigation Practice, The Twelfth Rankine Lecture," Geotechnique 22, No. 2, February 1972, pp. 195-300. 